Vegetalika. 2017. 6(3): 1-11

\title{
Pengaruh Ketebalan Abu Volkan di Atas Permukaan Tanah yang Jatuh pada Berbagai Fase Tumbuh terhadap Pertumbuhan dan Hasil Jagung (Zea Mays L.)
}

\section{The Influence of Volcanic Ash Thickness in the Soil Surface that Fell Various of Growth Phases to the Growth and Result of Maize (Zea Mays L.)}

\author{
Ganang Rudianto'), Didik Indradewa ${ }^{2 *}$, Sri Nuryani Hidayah Utami ${ }^{2)}$ \\ 1) Program Studi Agronomi, Fakultas Pertanian, Universitas Gadjah Mada \\ 2) Departemen Budidaya Pertanian, Fakultas Pertanian, Universitas Gadjah Mada \\ ${ }^{*}$ Penulis untuk korespodensi E-mail: didikindradewa54@yahoo.com
}

\begin{abstract}
Crops planting was done continuously, on the other hand that volcano's eruption was not predicted. Volcanic dust as the result of Kelud Mountains's eruption in 2014 walked into southwest (Yogyakarta) in hundreds kilometers. Maize was one of the crops that grew in lowland until plateau land. Maize growth stage with the volcanic dust was different, and it depended on the time when the eruption was done. This research was done in Dusun Peni, Palbapang, Bantul Regency, Yogyakarta. It started at June-September, 2016. This research was arranged in randomized completely block design two factors with three blocks replications. Observation data was analyzed by Analysis of Variants (ANOVA). If there was a significant difference, it was analyzed by Duncan with $5 \%$ in significance level. That analysis was done to know the comparison between each treatment. The research's result showed that the falling of the volcanic dust when the maize yet germinated caused the maize was not grow. Falling of the volcanic dust when the maize was 20 days old or in the vegetative phase showed the best growth, but the roots of the maize became the fiber roots.
\end{abstract}

Keywords: Zea mays L., thickness, volcanic dust

\section{INTISARI}

Erupsi gunung berapi tidak dapat diprediksi sedangkan menanam tanaman pangan dilakukan secara terus menerus. Abu volkan hasil erupsi gunung Kelud tahun 2014 mengarah ke barat daya yaitu ke arah Yogyakarta dengan jarak ratusan kilometer. Tanaman jagung adalah salah satu tanaman pangan yang dibudidayakan dari dataran rendah sanpai dataran tinggi. Stadia pertumbuhan tanaman jagung yang terkena abu volkan dapat berbeda-beda tergantung kapan erupsi gunung berapi terjadi. Penelitian ini telah dilaksanakan di Dusun Peni, Palbapang, Bantul, Yogyakarta mulai bulan JuniSeptember 2016. Penelitian disusun dalam rancangan acak kelompok lengkap (RAKL) faktorial dua faktor, dengan tiga ulangan. Data pengamatan dianalisis menggunakan analisis varian (ANOVA), apabila terdapat beda nyata dilakukan uji lanjut jarak berganda Duncan taraf nyata $5 \%$ guna mengetahui perbandingan antar perlakuan. Hasil penelitian 
menunjukkan bahwa abu volkan yang jatuh saat tanaman jagung belum berkecambah menyebabkan tanaman jagung tidak tumbuh. Abu volkan yang jatuh saat tanaman berumur 20 hari atau dalam fase vegetatif secara umum menunjukkan pertumbuhan dan hasil yang paling baik, akan tetapi akar tanaman menjadi serabut.

Kata kunci: Zea mays L., abu volkan, ketebalan abu volkan

\section{PENDAHULUAN}

Suatu aktivitas vulkanisme, material-material yang dikeluarkan berupa gas, cair, dan padat. Gas-gas yang keluar antara lain uap air, $\mathrm{O}_{2}, \mathrm{~N}_{2}, \mathrm{CO}_{2}, \mathrm{CO}, \mathrm{SO}_{2}, \mathrm{H}_{2} \mathrm{~S}, \mathrm{NH}_{3}$, $\mathrm{H}_{2} \mathrm{SO}_{4}$, dan sebagainya. Materi cair yang dikeluarkan adalah magma yang keluar melalui pipa gunung yang disebut lava sedangkan materi padat yang disemburkan ketika gunung api meletus berupa bom (batu-batu besar), kerikil, lapilli, pasir, abu serta debu halus (Munir, 1996).

Debu dan pasir vulkanik yang disemburkan keatas mulai dari berukuran besar sampai berukuran yang lebih halus. Debu dan pasir vulkanik ini merupakan salah satu batuan induk tanah yang nantinya akan melapuk menjadi bahan induk tanah dan selanjutnya akan mempengaruhi sifat dan ciri tanah yang terbentuk (Fiantis, 2006). Menurut Shoji dan Takahashi (2002) material ini merupakan bahan yang kaya akan unsurunsur hara, sehingga dapat memerbaharui sumber daya lahan. Meskipun demikian, timbunan material vulkanik dalam jumlah banyak juga dapat berdampak negatif bagi pertumbuhan tanaman terutama terhadap tanah sebagai media tumbuhnya. Masalah yang ditimbulkan pada lahan yang baru terdampak material vulkanik untuk dijadikan sebagai media tanam adalah sifat fisik, kimia dan biologinya yang tidak mendukung pertumbuhan tanaman secara optimal.

Abu volkan mengandung Si yang banyak sehingga dapat dimanfaatkan oleh tanaman. Manfaat unsur Si pada tanaman-tanaman graminea, terutama padi dan tebu cukup penting dan telah diketahui sejak lama. Si diperlukan untuk menjadikan tanaman memiliki bentuk daun yang tegak (tidak terkulai), sehingga daun efektif menangkap radiasi surya dan efisien dalam penggunaan hara $\mathrm{N}$ yang menentukan tinggi/ rendahnya hasil tanaman. Tanaman cukup Si memiliki daun yang terlapisi silikat dengan baik, menjadikannya lebih tahan terhadap serangan berbagai penyakit yang diakibatkan oleh fungi maupun bakteri seperti blas, HDB. Dengan Si, batang tanaman menjadi lebih kuat dan kekar, sehingga lebih tahan terhadap serangan penggerek batang, wereng coklat, dan 
Ganang Rudianto et al., / Vegetalika. 2017. 6(3): 1-11

tanaman menjadi tidak mudah rebah. Si juga menyebabkan perakaran tanaman lebih kuat, intensif, dan menaikkan root oxidizing power, yaitu kemampuan akar mengoksidasi lingkungannya (Makarim et al., 2007). Secara umum pemberian silikat dapat memperbaiki fungsi fisiologis tanaman dan meningkatkan ketahanan tanaman terhadap serangan hama, penyakit dan terhadap kerebahan. Pengaruh pemberian silikat paling nyata bila diberikan pada stadia generatif (perpanjangan bakal bunga), pemberian pada stadia vegetatif pengaruhnya tidak begitu besar terhadap komponen hasil (Takahashi, 1995).

Erupsi gunung berapi terjadi atas kehendak alam yang tidak bisa diketahui kapan akan terjadi. Sampai saat ini penggunaan teknologi hanya bisa memprediksi erupsi gunung berapi melalui pendekatan perilaku gunung berapi atau memperkirakan fase erupsi gunung berapi dan seberapa besar erupsi yang akan terjadi. Apabila erupsi gunung berapi terjadi maka menyebabkan dampak terhadap lingkungan yang harus siap kapan pun terjadi. Material yang dikeluarkan dari gunung berapi berupa gas, cair dan padat. Abu volkan merupakan salah satu material yang dikeluarkan gunung berapi, banyaknya abu volkan yang keluar tergantung dari tipe magma dan besarnya letusan yang terjadi. Abu volkan yang berupa debu dapat menyebar mencapai ratusan kilometer dengan bantuan angin. Daerah yang dekat dengan sumber erupsi menyebabkan ketebalan abu volkan yang lebih tebal dari daerah yang lebih jauh dari sumber erupsi. Oleh karena itu pengaruh abu volkan diberbagai fase pertumbuhan dan ketebalan abu di atas tanah pada tanaman jagung perlu dibuktikan secara empiris.

\section{BAHAN DAN METODE}

Penelitian ini dilaksanakan pada bulan Juni - September 2016 di Dusun Peni, Palbapang, Bantul, DIY. Bahan yang digunakan adalah benih tanaman jagung (Zea mays L.), tanah, pupuk kimia sesuai rekomendasi dan abu volkan Gunung Kelud yang diambil di Yogyakarta.

Penelitian menggunakan rancangan acak kelompok lengkap dua faktor. Faktor pertama adalah ketebalan abu $4 \mathrm{~cm}$, ketebalan abu $8 \mathrm{~cm}$ dan ketebalan abu $12 \mathrm{~cm}$. Faktor kedua adalah waktu pemberian abu volkan yaitu saat awal tanam 0 hst, umur 20 hst, umur 45 hst dan umur 65 hst, sehingga diperoleh 12 kombinasi perlakuan yang diulang sebanyak 3 kali. Masing-masing perlakuan terdiri dari 18 tanaman, setiap tanaman ditanam dalam polibeg ukuran $50 \mathrm{~cm} \times 50 \mathrm{~cm}$. 
Pemupukan dilakukan dengan cara dibuat lubang sedalam 2-3 cm di sekitar tanaman lalu pupuk dimasukkan dan ditutup lagi dengan tanah. Pupuk dasar sebanyak 0,813 gram Urea, 0,97 gram SP-36 dan 0,58 gram $\mathrm{KCl}$ untuk setiap polibeg. Pupuk selanjutnya diaplikasikan pada fase V6 sebanyak 1,897 gram Urea per polibeg.

Data hasil pengamatan (tinggi tanaman, jumlah daun, diameter batang, berat kering akar, berat kering tajuk, berat kering total, luas daun, diameter tongkol, panjang tongkol, bobot 100 biji, dan berat pipilan dianalisis dengan analisis varian dengan taraf kepercayaan 95\%. Apabila terdapat interaksi antara dua faktor maka dilakukan uji lanjut DMRT terhadap pengaruh sederhananya dan apabila tidak ditemukan interaksi maka dilakukan uji lanjut DMRT taraf $5 \%$ terhadap pengaruh utamanya.

\section{HASIL DAN PEMBAHASAN}

Kondisi lingkungan penelitian (Juni-September 2016), suhu udara berkisar antara $30,7-33,4^{\circ} \mathrm{C}$ dan kelembaban udara $67-72 \%$. Berdasarkan hasil pengamatan iklim mikro, lokasi penelitian mendukung pertumbuhan dan perkembangan tanaman jagung, Harniati (2002) menyebutkan bahwa suhu ideal untuk tanaman jagung adalah $23-27^{\circ} \mathrm{C}$. Namun, jagung masih dapat tumbuh dengan baik pada daerah dengan kisaran suhu $21-34^{\circ} \mathrm{C}$. Jagung merupakan tanaman yang relatif toleran terhadap kekeringan dan dapat tumbuh dengan baik pada lingkungan dengan kelembaban udara 42-80\%. Selanjutnya menurut Barnito (2009) tanaman jagung membutuhkan kelembaban udara sedang sampai dengan tinggi (50\%-80\%) agar keseimbangan metabolism tanaman dapat berlangsung dengan optimal.

Tabel 1. Komposisi abu volkan gunung kelud

\begin{tabular}{clc}
\hline No & Parameter & Hasil Pengukuran (\%) \\
\hline 1. & $\mathrm{SiO}_{2}$ & 55,24 \\
2. & $\mathrm{Al}_{2} \mathrm{O}_{3}$ & 18,70 \\
3. & $\mathrm{Fe}_{2} \mathrm{O}_{3}$ & 8,71 \\
4. & $\mathrm{MgO}$ & 3,50 \\
5. & $\mathrm{CaO}$ & 9,09 \\
6. & $\mathrm{Na}_{2} \mathrm{O}$ & 3,11 \\
7. & $\mathrm{~K}_{2} \mathrm{O}$ & 0,83 \\
8. & $\mathrm{TiO}_{2}$ & 0,62 \\
9. & $\mathrm{MnO}$ & 0,20 \\
\hline
\end{tabular}

Sumber: Bourder et al. (1997) 
Ganang Rudianto et al., / Vegetalika. 2017. 6(3): 1-11

Berdasarkan Tabel 1 di atas diketahui bahwa abu volkan mengandung sejumlah unsur-unsur, baik unsur hara makro maupun mikro yang dibutuhkan tanaman. Unsur hara makro yang terdapat dalam abu volkan yaitu $\mathrm{K}, \mathrm{Ca}$ dan $\mathrm{Mg}$. kemudian unsur hara mikro yang terdapat dalam abu volkan yaitu $\mathrm{Si}$, $\mathrm{Al}$, Fe dan $\mathrm{Mn}$. Kandungan tertinggi yang terdapat dalam abu volkan ialah $\mathrm{SiO}_{2}(55,24 \%)$ dan yang terendah ialah $\mathrm{MnO}(0,2 \%)$.

Tabel 2. Infiltrasi tanah

\begin{tabular}{lccc}
\hline \multicolumn{1}{c}{ Material } & $\begin{array}{c}\text { Tebal abu } \\
\text { volkan }(\mathrm{cm})\end{array}$ & $\begin{array}{c}\text { Laju infiltrasi } \\
(\mathrm{mm} / \mathrm{jam})\end{array}$ & $\begin{array}{c}\text { Klasifikasi } \\
(\text { Lee,1990) }\end{array}$ \\
\hline Tanah sawah & - & 4,89 & Lambat \\
Tanah sawah dan abu volkan & 4 & 2,94 & Lambat \\
Tanah sawah dan abu volkan & 8 & 0,57 & Sangat lambat \\
Tanah sawah dan abu volkan & 12 & 0,45 & Sangat lambat \\
\hline
\end{tabular}

Berdasarkan Tabel 2 diatas semakin tebal abu volkan maka semakin kecil laju infiltrasi atau dapat dikatakan aju infiltrasi semakin lambat. Infiltrasi pada tanah tertutup abu jauh lebih kecil dibandingkan tanah yang tidak tertutup abu volkan. Menurut Ningsih (2012) penyebabnya adalah ukuran butir abu yang sangat halus, memiliki gaya kapiler yang tinggi. Juga sifat lapisan abu yang akan cepat mengeras pada kondisi basah. Lapisan yang keras tersebut disebut crust yang terjadi karena abu memiliki gaya kohesi yang tinggi saat basah. Lapisan ini menjadikan air sulit terinfiltrasi, dan laju infiltrasi menjadi cepat konstan.

Tabel 3. Panjang akar umur $14 \mathrm{mst}(\mathrm{cm})$

\begin{tabular}{|c|c|c|c|c|c|c|c|c|}
\hline \multirow{2}{*}{$\begin{array}{c}\text { Umur Jagung } \\
\text { Saat Tertutup } \\
\text { Abu Volkan } \\
\text { (Hari) }\end{array}$} & \multicolumn{6}{|c|}{ Ketebalan Abu Volkan (cm) } & \multirow[b]{2}{*}{ Rerata } & \\
\hline & 4 & & 8 & & 12 & & & \\
\hline 20 & 2203,00 & a & 2028,80 & $a b$ & 1785,40 & bc & 2005,73 & \\
\hline 45 & 1638,70 & $\mathrm{~cd}$ & 1305,30 & de & 1662,00 & bcd & 1535,36 & \\
\hline 55 & 1468,00 & cde & 1553,60 & $\mathrm{~cd}$ & 1142,40 & $\mathrm{e}$ & 1388,00 & \\
\hline Rerata & 1769,90 & & 1629,23 & & 1529,96 & & 1643,03 & $p$ \\
\hline Kontrol & & & & & & & 1207,87 & $\mathrm{q}$ \\
\hline
\end{tabular}

Keterangan: Kombinasi dibandingkan dengan Kontrol menggunakan kontras. Rerata yang diikuti huruf sama dalam suatu kolom yang sama menunjukkan tidak berbeda signifikan menurut uji DMRT 5\%. 
Abu volkan yang jatuh saat tanam (0 hari), menghambat perkecambahan biji jagung, sehingga jagung tidak ada yang tumbuh. Hal ini dikarenakan sifat abu volkan ketika abu volkan jatuh dan menutup tanah dalam keadaan kering cenderung panas karena terpapar sinar matahari dan ketika abu volkan terkena air maka abu volkan akan mengeras sehingga kecambah sulit untuk tumbuh. Hal ini sejalan dengan Suriadikarta et al., (2010) yang menyatakan salah satu material piroklastik, abu vulkanik, memiliki sifat yang cepat mengeras dan sulit ditembus oleh air, baik dari atas maupun dari bawah permukaan. Terjadi interaksi antara waktu jatuhnya dengan ketebalan abu volkan. Bila abu volkan menutup tanah saat tanaman berumur 20 hari maka semakin tebal abu volkan semakin pendek panjang akar. Tetapi ketika umur tanaman 45 hari lalu abu jatuh maka ketebalan abu volkan $8 \mathrm{~cm}$ menyebabkan panjang akar lebih pendek walau tidak berbeda nyata. Berbeda ketika abu volkan jatuh saat tanaman berumur 55 hari ada kecenderunganwalau tidak berbeda nyata semakin tebal abu volkan yang menutup tanah menyebabkan panjang akar lebih panjang, tetapi ketika ketebalan abu $12 \mathrm{~cm}$ berpengaruh paling buruk terhadap panjang akar. Tanaman jagung yang terkena abu volkan menyebabkan panjang akar lebih panjang dari pada tanaman yang tidak terkena abu volkan.

Tabel 4. Luas total akar umur $14 \mathrm{mst}\left(\mathrm{cm}^{2} /\right.$ tanaman)

\begin{tabular}{|c|c|c|c|c|c|c|c|c|}
\hline \multirow{2}{*}{$\begin{array}{c}\text { Umur Jagung } \\
\text { Saat Tertutup } \\
\text { Abu Volkan } \\
\text { (Hari) }\end{array}$} & \multicolumn{6}{|c|}{ Ketebalan Abu Volkan (cm) } & \multirow{2}{*}{\multicolumn{2}{|c|}{ Rerata }} \\
\hline & 4 & & 8 & & 12 & & & \\
\hline 20 & 767,39 & $a$ & 704,90 & $b$ & 694,67 & $b$ & 722,32 & \\
\hline 45 & 654,23 & c & 630,46 & c & 638,13 & c & 640,94 & \\
\hline 55 & 620,63 & C & 649,43 & c & 618,93 & C & 629,66 & \\
\hline Rerata & 680,75 & & 661,59 & & 650,57 & & 664,31 & $p$ \\
\hline Kontrol & & & & & & & 603,42 & $q$ \\
\hline
\end{tabular}

Keterangan: Kombinasi dibandingkan dengan Kontrol menggunakan kontras. Rerata yang diikuti huruf sama dalam suatu kolom yang sama menunjukkan tidak berbeda signifikan menurut uji DMRT 5\%.

Adanya abu volkan dapat meningkatkan luas permukaan akar pada 14 MST Terjadi interaksi antara kapan jatuhnya abu volkan dan ketebalan abu volkan di atas permukaan tanah. Terdapat kecederungan, semakin tebal abu volkan menutupi permukaan tanah, semakin menurun luas permukaan akar, namun tergantung kepada kapan jatuhnya abu volkan. Bila abu volkan jatuh saat tanaman berumur 20 hari, semakin tebal abu volkan, semakin menurun luas permukaan akar, meskipun antara ketebalan 8 
Ganang Rudianto et al., / Vegetalika. 2017. 6(3): 1-11

tidak berbeda pengaruhnya dengan ketebalan $12 \mathrm{~cm}$. Bila abu volkan jatuh pada 45 hari, tidak ada perbedaan pengaruh ketebalan abu volkan. Bila Abu volkan jatuh saat 55 hari, ketebalan 12 berpengaruh lebih buruk terhadap luas permukaan akar.

Tabel 5. Volume akar umur $14 \mathrm{mst}\left(\mathrm{cm}^{3}\right)$

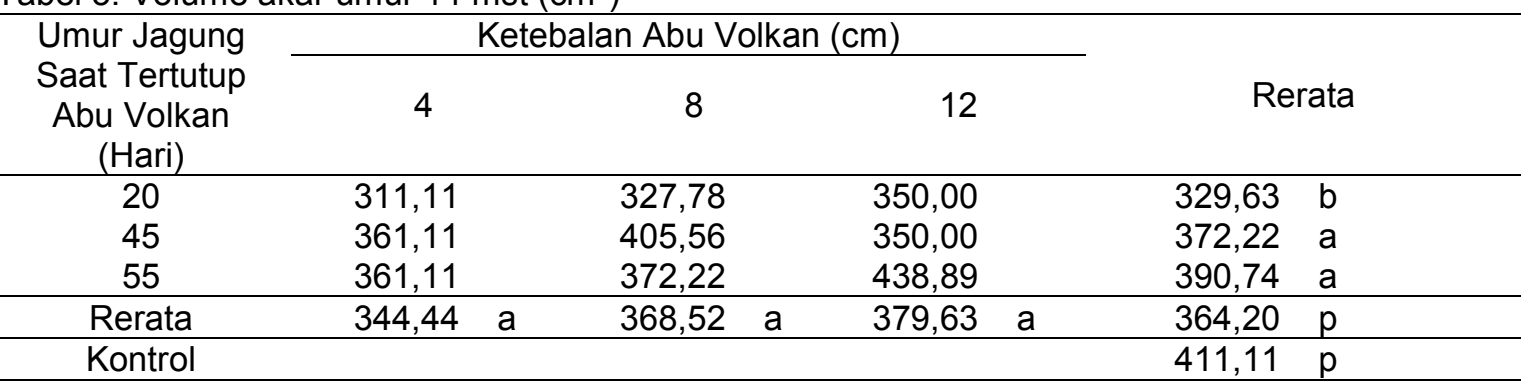

Keterangan: Kombinasi dibandingkan dengan Kontrol menggunakan kontras. Rerata yang diikuti huruf sama dalam suatu kolom atau baris yang sama menunjukkan tidak berbeda nyata menurut uji DMRT 5\%.

Perlakuan yang tidak terkena abu volkan tidak ada perbedaan yang nyata dengan perlakuan dengan abu volkan. Tidak terjadi interaksi antara ketebalan abu volkan dengan waktu jatuhnya abu volkan pada tanaman jagung terhadap volume akar. Tabel menunjukkan bahwa bila abu volkan menutup tanah pada saat jagung berumur 55 dan 45 hari, volume akar lebih besar dibanding bila tertutup pada umur yang lebih muda yaitu 20 hari. Penutupan abu volkan pada umur 45 dengan 55 hari tidak ada perbedaan pengaruh yang nyata.

Abu volkan yang jatuh saat tanaman berumur 20 hari dengan ketebalan $4 \mathrm{~cm}$ berpengaruh nyata pada parameter panjang akar dan luas total akar yang menyebabkan nilai paling tinggi. Kemudian pada paremeter volume akar menyebabkan volume terkecil. Hal ini kemungkinan akar yang terbatasi perkembangannya karena abu volkan yang mengeras beradaptasi atau memodifikasi pertumbuhannya dengan menumbuhkan akar yang lebih kecil (serabut), sehingga akar serabut tersebut masih tetap bisa mencari hara di dalam tanah. Akar serabut yang banyak membuat luas total akar lebih luas. 
Tabel 6. Jumlah daun umur 14 mst (helai)

\begin{tabular}{|c|c|c|c|c|c|}
\hline \multirow{2}{*}{$\begin{array}{c}\text { Umur Jagung } \\
\text { Saat Tertutup } \\
\text { Abu Volkan } \\
\text { (Hari) }\end{array}$} & \multicolumn{3}{|c|}{ Ketebalan Abu Volkan $(\mathrm{cm})$} & \multirow{2}{*}{\multicolumn{2}{|c|}{ Rerata }} \\
\hline & 4 & 8 & 12 & & \\
\hline 20 & 9,11 & 9,67 & 10,11 & 9,63 & a \\
\hline 45 & 8,22 & 8,33 & 8,33 & 8,30 & b \\
\hline 55 & 8,00 & 8,22 & 9,11 & 8,44 & b \\
\hline Rerata & $8,45 b$ & $8,74 a b$ & $9,19 a$ & 8,79 & $\mathrm{p}$ \\
\hline Kontrol & & & & 8,22 & $\mathrm{p}$ \\
\hline
\end{tabular}

Tanaman yang tidak terkena abu volkan jumlah daunnya tidak berbeda nyata dengan tanaman yang terkena abu volkan. Tidak terjadi interaksi antara waktu jatuhnya dengan ketebalan abu volkan. Terdapat perbedaan jumlah daun terhadap waktu jatuhnya abu volkan, abu volkan yang jatuh saat tanaman berumur 20 hst menyebabkan jumlah daun paling banyak dibandingkan dengan jatuhnya abu volkan saat tanaman yang lebih tua. Umur penutupan abu volkan saat 45 dengan 55 hari tidak ada perbedaan pengaruh yang nyata. Jumlah daun yang paling banyak saat ketebalan abu volkan $12 \mathrm{~cm}$ akan tetapi tidak berbeda nyata terhadap ketebalan abu volkan $8 \mathrm{~cm}$, begitu juga dengan ketebalan abu volkan $4 \mathrm{~cm}$ tidak berbeda nyata terhadap ketebalan abu volkan $8 \mathrm{~cm}$. Jumlah daun saat ketebalan abu volkan $12 \mathrm{~cm}$ berbeda nyata terhadap jumlah daun saat abu volkan 4 $\mathrm{cm}$.

Ada kecenderungan semakin tebal abu volkan semakin banyak jumlah daun pada tanaman jagung saat umur 14 mst. Hal ini dikarenakan silika banyak terdapat pada lapisan epidermis di daun, pelepah daun dan batang (Takahashi 1995). Silikat diserap oleh akar, ditranslokasikan ke daun sehingga jaringan tersebut mengeras akibat Si sehingga daun jagung terjaga dari kepatahan. Pada parameter bobot kering total bila abu volkan jatuh saat tanaman berumur 20 hari, maka semakin tebal abu volkan, semakin meningkat bobot kering total. Akan tetapi ketika ketebalan abu volkan $12 \mathrm{~cm}$ bobot kering total mengalami penurunan. Menurut Ma dan Yamaji (2006) silika yang berada di batang, daun dan kulit tanaman meningkatkan kekuatan dan kekakuan dinding sel. Akan tetapi ketika ketebalan abu $12 \mathrm{~cm}$ maka bobot kering total mengalami penurunan dibandingkan dengan bobot kering total dengan ketebalan $8 \mathrm{~cm}$. Hal ini karena tanaman masih dalam fase vegetatif ketika abu volkan jatuh, sehingga tanaman menyerap hara lebih banyak. Silika yang 
Ganang Rudianto et al., / Vegetalika. 2017. 6(3): 1-11

terserap oleh tanaman juga banyak akan tetapi ketika ketebalan abu $12 \mathrm{~cm}$ maka abu volkan juga membatasi perkembangan akar sehingga penyerapan hara terganggu. Ketika abu volkan menutup tanah saat tanaman berumur 45 dan 55 hari bobot kering total tidak berbeda nyata dengan ketebalan abu volkan 4-12 $\mathrm{cm}$. Abu volkan yang menutup tanah saat tanaman berumur 55 hari dengan ketebalan $4 \mathrm{~cm}$ berpengaruh lebih buruk terhadap bobot kering total. Hal ini dikarenakan saat umur $14 \mathrm{mst}$ tanaman jagung sudah memasuki masa panen, sehingga fotosintat tanaman sudah ditranslokasikan ke bagian generatif tanaman atau ke tongkol jagung. Pada ketebalan abu volkan $4 \mathrm{~cm}$ pengaruh terhadap bobot kering total lebih kecil dari pada ketebalan 8 dan $12 \mathrm{~cm}$ dikarenakan silika yang terkandung juga lebih sedikit dari ketebalan lain.

Tabel 7. Bobot kering total $14 \mathrm{mst}$ (g/tanaman)

\begin{tabular}{|c|c|c|c|c|c|c|c|c|}
\hline \multirow{2}{*}{$\begin{array}{c}\text { Umur Jagung } \\
\text { Saat Tertutup } \\
\text { Abu Volkan } \\
\text { (Hari) }\end{array}$} & \multicolumn{6}{|c|}{ Ketebalan Abu Volkan (cm) } & \multirow{2}{*}{\multicolumn{2}{|c|}{ Rerata }} \\
\hline & 4 & & 8 & & 12 & & & \\
\hline 20 & 205.83 & $\mathrm{~b}$ & 213.55 & $a$ & 199.28 & $b$ & 206.22 & \\
\hline 45 & 178,93 & $\mathrm{~cd}$ & 186.69 & c & 185.63 & c & 183.75 & \\
\hline 55 & 173.98 & $\mathrm{~d}$ & 178.92 & $\mathrm{~cd}$ & 180.99 & $\mathrm{~cd}$ & 177.96 & \\
\hline Rerata & 186.24 & & 193.05 & & 188.63 & $(+)$ & 189.31 & $p$ \\
\hline Kontrol & & & & & & & 189.72 & $p$ \\
\hline
\end{tabular}

Tabel 8. Indeks panen tanaman jagung

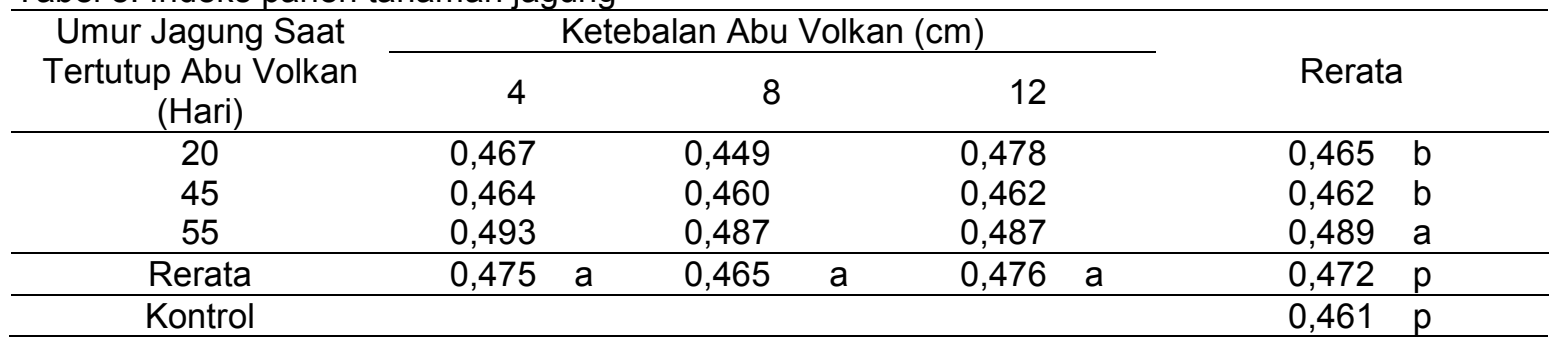

Keterangan: Rerata yang diikuti huruf sama dalam suatu kolom yang sama menunjukkan tidak berbeda signifikan menurut uji DMRT 5\%. Tanda (-) menunjukkan tidak adanya interaksi antar perlakuan.

Indeks panen yang rendah menunjukkan proporsi bobot kering biji jagung lebih sedikit dibandingkan total bobot kering tanaman. Tanaman jagung yang tidak terkena abu volkan tidak memberikan perbedaan yang nyata dengan tanaman jagung yang tanahnya tertutup abu volkan. Ketebalan abu volkan tidak berbeda nyata terhadap indeks panen. Bila abu volkan jatuh saat tanaman jagung berumur 65 hari maka indeks panen turun dari pada abu volkan jatuh saat tanaman jagung berumur 20 dan 45 hari. 
Tabel 9. Bobot pipilan (gram/tongkol)

\begin{tabular}{|c|c|c|c|c|c|c|c|c|}
\hline \multirow{2}{*}{$\begin{array}{c}\text { Umur Jagung Saat } \\
\text { Tertutup Abu Volkan } \\
\text { (Hari) }\end{array}$} & \multicolumn{6}{|c|}{ Ketebalan Abu Volkan (cm) } & \multirow{2}{*}{\multicolumn{2}{|c|}{ Rerata }} \\
\hline & 4 & & 8 & & 12 & & & \\
\hline 20 & 180,17 & & 174,55 & & 182,55 & & 178,91 & $a$ \\
\hline 45 & 155,19 & & 158,90 & & 159,26 & & 157,79 & $\mathrm{c}$ \\
\hline 55 & 169,27 & & 169,69 & & 171,55 & & 170,17 & $\mathrm{~b}$ \\
\hline Rerata & 168,21 & $\mathrm{a}$ & 167,54 & $a$ & 171,12 & $\mathrm{a}$ & 168,96 & $p$ \\
\hline Kontrol & & & & & & & 162,27 & $p$ \\
\hline
\end{tabular}

Ketebalan abu volkan tidak menyebabkan perbedaan yang nyata terhadap bobot pipilan jagung. Tanaman jagung yang terkena abu volkan tidak berbeda nyata dengan tanaman jagung yang tidak terkena abu volkan. Tidak ada interaksi antara waktu jatuhnya dan ketebalan abu volkan terhadap bobot pipilan. Bila abu volkan jatuh saat tanaman berumur 20 hari menyebabkan bobot pipilan terberat dari pada abu volkan jatuh saat tanaman jagung berumur 45 dan 55 hari. Akan tetapi bila abu volkan jatuh saat tanaman berumur 45 hari menyebabkan bobot pipilan terendah. Hal ini berarti abu volkan berpengaruh buruk ketika jatuh saat tanaman berumur 45 atau saat malai mulai muncul. Sedangkan bobot pipilan terberat pada saat tanaman berumur 20 hari terkena abu volkan. Hal ini kemungkinan dikarenakan pada saat abu jatuh ketika tanaman berumur 20 hari memiliki parameter pertumbuhan yang lebih tinggi dari pada ketika abu jatuh saat 45 maupun 55 hari. Parameter pertumbuhan yang lebih tinggi ketika abu jatuh saat tanaman berumur 20 hari ialah tinggi tanaman, jumlah daun, luas daun, diameter batang, bobot segar tajuk, bobot kering tajuk, bobot kering total dan luas akar saat 8 dan 14 mst. Secara umum, tanaman yang memiliki pertumbuhan vegetatif yang baik akan memiliki komponen hasil yang baik.

\section{KESIMPULAN}

1. Semakin tebal abu volkan yang jatuh di atas permukaan tanah laju infiltrasi air semakin menurun.

2. Abu volkan yang jatuh saat benih belum berkecambah menyebabkan benih tidak dapat tumbuh. 
Ganang Rudianto et al., / Vegetalika. 2017. 6(3): 1-11

3. Abu volkan yang menutup tanah ketika tanaman jagung sudah tumbuh tidak mempengaruhi pertumbuhan dan hasil tanaman jagung.

\section{DAFTAR PUSTAKA}

Barnito, N., 2009. Budidaya tanaman jagung. Suka Abadi. Yogyakata.

Fiantis, D., 2006. Laju Pelapukan Kimia Debu Vulkanis G. Talang dan Pengaruhnya Terhadap Proses Pembentukan Mineral Liat Non-Kristalin. Universitas Andalas, Padang.

Harniati, U. 2002. Keunggulan dan kelemahan sistem alley cropping serta peluang dan kendala adopsinya di lahan kering das bagian hulu. <http://216.239.33.100/search?q:rudyct.tripod.com/sem1_023/umi_haryti.htm +lahan+kering\&hl>. Diakses pada 18 Agustus 2016.

Ma, Jian Feng and Naoki Yamaji. 2006. Silicon uptake and accumulation in higher plants. TRENDS in Plant Science Vol 11.

Makarim, A.K. E. Suhartatik dan A. Kartohardjono. 2007. Silikon: hara penting pada sistem produksi padi. Iptek Tanaman Pangan. Vol 2:195-204.

Munir, M., 1996. Tanah - tanah utama Indonesia. Pustaka Jaya, Jakarta.

Ningsih, Sri. 2012. Kajian laju infiltrasi tanah dan imbuhan air tanah lokal sub das gendol pasca erupsi merapi 2010. Jurnal Bumi Indonesia. 1:218-226.

Shoji, S. \& Takahashi, T., 2002. Environmental and Agricultural Significance of Volcanic Ash Soils. Jpn. J. Soil Sci. Plant Nutr. 73: 113-135.

Suriadikarta, D.A., Abbas, A., Sutono, Erfandi, D., Santoso, E., Kasno, A., 2010. Identifikasi Sifat Kimia Abu Volkan, Tanah dan Air di Lokasi Dampak Letusan Gunung Merapi. Bogor : Balai Penelitian Tanah.

Takahashi, E. 1995. Uptake model and physiological functions of silica. In: T. Matsuo, K. Kumazawa, R. Ishii, K. Ishihara, and H. Hirata (Eds.). Science of Rice Plant, Physiology. Food and Agriculture Research Center, Tokyo. 2:420-433. 